\title{
Prevalence of High-Risk Human Papilloma Virus and Identification of Type Using Real-Time Polymerase Chain Reaction Analysis and Liquid-Based Cytology
}

\author{
Nagehan Özdemir Barışık, Sevinç Hallaç Keser, ${ }^{1}$ Aylin Ege Gül, \\ Engin Ersin Şimşek, ${ }^{2}$ Hanife Gülnihal Özdemir ${ }^{1}$
}

'Department of Pathology, Kartal Dr. Lütfi Kırdar Training and Research Hospital, İstanbul, Turkey

${ }^{2}$ Department of Family Medicine, Kartal Dr. Lütfi Kırdar Training and Research Hospital, İstanbul, Turkey

Submitted: 12.10 .2017 Accepted: 18.10.2017

Correspondence: Nagehan Özdemir Barışık Kartal Dr. Lütfi Kırdar Eğitim Araştırma Hastanesi Patoloji Kliniği, İstanbul, Turkey

E-mail: nagehanob@yahoo.com

Keywords: Cervical cytology; human papilloma virus DNA; real-time polymerase chain reaction.

\begin{abstract}
Objective: Cervical cytology samples were analyzed to determine the prevalence of human papilloma virus infection (HPV) and the most frequently observed types. Methods used to assess the presence of HPV were also evaluated.

Methods: A total of 837 female patients who presented at the hospital between June 2016 and March 2017 were retrospectively included in the study. Real-time polymerase chain reaction (RT-PCR) analysis was used to detect the presence and identify the type of HPV, and a liquid-based cytology technique was also used to evaluate cervical cytology in concurrently obtained samples taken during a gynecological examination.
\end{abstract}

Results: Of 837 cervical cytology samples, squamous cell atypia (SCA) was seen in 208 (24.9\%) samples, and was not present in the remaining 629 (75.1\%). Analysis of the samples with SCA revealed the presence of SCA of undetermined significance in I42 (I7.0\%), lowgrade squamous intraepithelial lesion in $53(6.3 \%)$, and high-grade squamous intraepithelial lesion in $13(1.6 \%)$ samples. HPV-positivity was detected in 344 of the 837 patients (4I.I\%). The most frequently seen types were HPV 16, 18, 31, and 5I. HPV prevalence was greatest in women younger than 30 years of age and those over 50. HPV 16 and multiple strains were most often seen in women under 30 . HPV 16 was the most frequently seen single HPV strain, followed by HPV types 5I, 3I, and I8, respectively. HPV 16 was also most common among samples with multiple strains, followed by types 31 , $5 \mathrm{I}$, and I8, respectively. HPV-positivity was detected in $132(63.5 \%)$ patients with SCA. Of the 629 who had an SCA-negative result, HPV positivity was determined in 212 (33.7\%) cases.

Conclusion: The most frequently detected strain of HPV in this study was type 16. HPV prevalence demonstrated a bimodal age distribution. HPV was correlated with SCA; however, HPV-positivity was also observed using RT-PCR in cases without SCA. This indicates the importance of the combination of RT-PCR and cytological examination in the determination of HPV types and prevalence, and in the treatment and follow-up of HPV-positive patients.

\section{INTRODUCTION}

Worldwide, cervical cancer is the second most frequently seen cancer among women, and it is the fifth leading cause of cancer death in the USA. ${ }^{[I]}$ It has been reported that every year it affects $0.0016 \%$ of the world population with an annual mortality rate of $0.009 \%{ }^{\left[{ }^{[1]}\right.}$ According to recent statistics, in Turkey, it is the II th most frequently seen cancer in women. In our country, some 30.1I million women are at risk of developing cervical cancer. Every year, an estimated 1686 women are diagnosed with cervical cancer, and 663 die of the disease. ${ }^{[2]}$

Human papilloma virus (HPV) has been accepted as the main etiological factor in cervical cancer; it has been estimated that $99.7 \%$ of these patients are HPV-positive. [3] More than I00 HPV genomes have been described. 
Among them, HPV types I6, I8, 3I, 33, 34, 35, 39, 45, 5I, $52,56,58,59,66,68$, and 70 are associated with cervical intraepithelial neoplasia and cervical cancer, and have been grouped as high-risk HPV (HR-HPV) types. ${ }^{[4]}$ Globally, the prevalence of HPV infection in various communities varies between $2 \%$ and $44 \% .^{[5]}$ In our country, among low-risk women, the prevalence of HPV ranges between $1.5 \%$ and $32.1 \% .{ }^{[2]}$ A bimodal age distribution pattern for HPV infection has been reported in some studies. The first peak for HPV infection has been indicated to manifest from the onset of sexual activity until age 30 , while the second peak is postmenopausal. ${ }^{[6]}$ In Turkey, HPV infection is most frequently seen among those under 30 years of age, and its prevalence decreases with age. ${ }^{[7,8]}$

The results of a cervical cytological examination are important in the determination and treatment of an HPV infection. Real-time polymerase chain reaction (RT-PCR) analysis is a precise, modern method to ascertain HPV type. ${ }^{[9]}$

The aim of this study was to determine the prevalence of HPV infection, the distribution of HPV types among age groups, and the rate of HPV infection in both normal and abnormal cervical cytology samples using both liquid-based cytology and RT-PCR methods, and to evaluate the results in order to contribute to HPV statistics in our country.

\section{MATERIAL AND METHODS}

Cervical cytology and HPV test samples sent to the pathology laboratory of the hospital between June 2016 and March 2017 were analyzed. The results were evaluated retrospectively. Samples were evaluated using liquid-based cytology and the RT-PCR method to assess the presence of HPV types 16, I8, 3I, 33, 35, 39, 45, 5I, 52, 56, 58, 59, 66 , and 68. Patients who had not undergone a concurrent HPV test and cervical cytology test, and those with missing or inadequate cervical cytology data were excluded from the study.

\section{Preparation of the sample}

The samples were prepared using liquid-based cytology (ThinPrep; Hologic, Inc., Marlborough, MA, USA). Slides were stained using the Papanicolaou (Pap) technique. The Bethesda System for Reporting Cervical Cytology (2014) was used to classify the samples. The first category was negative for intraepithelial lesion or malignancy. When the result was cytologically positive for squamous cell atypia (SCA), they were categorized as atypical squamous cells of undetermined significance (ASCUS) or atypical squamous cells with the inability to exclude high-grade squamous intraepithelial lesion (ASC-H). The final groups were lowgrade squamous intraepithelial lesion (LSIL) and definitive presence of high-grade squamous intraepithelial lesion (HSIL).

\section{Identification and genotyping of HPV DNA}

A portion of the cervical samples was immersed in a transport medium (PreservCyt; Hologic, Inc., Marlborough, MA, USA) for liquid-based cytological examination, and the RT-PCR procedure was applied to the remainder.

For DNA extraction, the QIA Amp DNA Mini Kit (Qiagen, Hiden, Germany) was used according to the instructions of the manufacturer. The $150 \mathrm{bp}$ fragment of the LI gene was amplified. The amplified gene product was imaged using a molecular beacon, an oligonucleotide probe that emits fluorescence. The HPV Genotypes I4 Real-TM Quant RT-PCR kit (Sacace Biotechnologies, Como, Italy) was used for genotyping.

The protocol of this study was approved by the Kartal Dr. Lütfi Kırdar Training and Research Hospital Ethics Committee (2017/5 I4/III/4).

\section{Statistical analysis}

Statistical analyses were performed using IBM SPSS Statistics for Windows, Version 23.0 (IBM Corp., Armonk, NY, USA) software. The fitness of variables to a normal distribution pattern was examined via visual (histogram and probability limits) and analytical tests (KolmogorovSmirnov/Shapiro-Wilk tests). Descriptive analyses were expressed as mean and standard deviation for variables with normal distribution. They were compared using the Pearson chi-square and Fischer's exact tests in $2 \times 2$ tables. When the table was larger, the Bonferroni correction and post-hoc analyses were used. $\mathrm{P}<0.05$ was accepted as the level of statistical significance.

\section{RESULTS}

Cervical cytology material and cervical smears obtained simultaneously during a 10-month period from 837 women with a mean age of $41.02 \pm 10.37$ years (range: 18-73 years) were analyzed for the presence of HPV infection.

SCA was seen in 208 (24.9\%) cytology samples. Glandular cell atypia and squamous cell carcinoma were not detected among the samples included in the study. The distribution of cervical cytology classification according to age group is shown in Table I.

RT-PCR analysis detected HPV-positivity in 344 (4I.I\%) of the patients. The presence of the most frequently seen HPV types (HPV types 16, 18, 3I, and 5I), as a single strain or multiple HPV types, are presented in Table 2.

Sixty-four (55.2\%) HPV-positive patients were younger than 30 years of age. An increased HPV prevalence, and the presence of HPV I6, in single or multiple strains, were also more frequently detected in the age group of $\leq 30$ years. The distribution of HPV types according to age group is in Table 3. 
Table I. Cytology results according to age group

\begin{tabular}{|c|c|c|c|c|c|c|c|c|c|c|c|}
\hline & \multicolumn{2}{|c|}{$<30$ years } & \multicolumn{2}{|c|}{ 30-39 years } & \multicolumn{2}{|c|}{$40-49$ years } & \multicolumn{2}{|c|}{$\geq 50$ years } & \multicolumn{2}{|c|}{ Total } & \multirow[t]{2}{*}{$\mathbf{p}$} \\
\hline & $\begin{array}{c}\text { Count } \\
\text { (n) }\end{array}$ & $\begin{array}{c}\text { Column } \\
\text { (\%) }\end{array}$ & $\begin{array}{c}\text { Count } \\
\text { (n) }\end{array}$ & $\begin{array}{c}\text { Column } \\
\text { (\%) }\end{array}$ & $\begin{array}{c}\text { Count } \\
\text { (n) }\end{array}$ & $\begin{array}{c}\text { Column } \\
\text { (\%) }\end{array}$ & $\begin{array}{c}\text { Count } \\
\text { (n) }\end{array}$ & $\begin{array}{c}\text { Column } \\
(\%)\end{array}$ & $\begin{array}{c}\text { Count } \\
\text { (n) }\end{array}$ & $\begin{array}{c}\text { Column } \\
\text { (\%) }\end{array}$ & \\
\hline \multicolumn{12}{|c|}{ Squamous cell atypia } \\
\hline No & 88 & 75.9 & 221 & 78.1 & 192 & 75.9 & 128 & 69.2 & 629 & 75.1 & 0.176 \\
\hline Yes & 28 & 24.1 & 62 & 21.9 & 61 & 24.1 & 57 & 30.8 & 208 & 24.9 & \\
\hline \multicolumn{12}{|l|}{ Smear } \\
\hline Negative & 88 & 75.9 & 221 & 78.1 & 192 & 75.9 & 128 & 69.2 & 629 & 75.1 & 0.007 \\
\hline ASCUS & 15 & 12.9 & 39 & 13.8 & 46 & 18.2 & 42 & 22.7 & 142 & 17.0 & \\
\hline LSIL & 13 & 11.2 & 19 & 6.7 & 13 & 5.1 & 8 & 4.3 & 53 & 6.3 & \\
\hline HSIL & 0 & 0.0 & 4 & 1.4 & 2 & 0.8 & 7 & 3.8 & 13 & 1.6 & \\
\hline
\end{tabular}

Fisher's exact test. ASCUS: Atypical squamous cells of undetermined significance; HSIL: High-grade squamous intraepithelial lesion; LSIL: Low-grade squamous intraepithelial lesion.

Table 2. Most frequently seen strains of human papilloma virus

\begin{tabular}{lcc}
\hline & n & $\%$ \\
\hline HPV I6 (Single/Multiple Strain) & $43 / 59$ & 12.2 \\
HPV I8 (Single/Multiple Strain) & $12 / 24$ & 4.3 \\
HPV 3I (Single/Multiple Strain) & $15 / 37$ & 6.2 \\
HPV 5I (Single/Multiple Strain) & $17 / 27$ & 5.3 \\
HPV positive (Single/Multiple Strain) & $196 / 148$ & 41.1 \\
HPV-negative & 493 & 58.9 \\
Total & 837 & 100.0 \\
\hline
\end{tabular}

HPV: Human papilloma virus.

Among those with SCA, HPV-positivity was detected in I 32 (63.5\%) samples.

HPV-positivity was seen in 212 (33.7\%) patients without SCA.

Concurrent determination of SCA and HPV is provided in Table 4.

A further detailed distribution of the most frequently seen HPV types by cytological classification is summarized in Table 5.

\section{DISCUSSION}

Cervical cancer is a global health problem with some 500,000 new cases every year, and a mortality rate of $50 \%$. ${ }^{[1]}$ In Turkey, it is the $\mathrm{I}^{\text {th }}$ most frequently seen malignancy in women and the $5^{\text {th }}$ most common cancer among women between 15 and 44 years of age. ${ }^{[2]}$

One of the historical milestones in defining the relationship between HPV and cervical cancer was a hypothesis published by zur Hausen in 1976 regarding the important role of HPV in the etiology of cervical cancer; another is the identification of HPV 16 and 18 by zur Hausen et al. in 1983 and 1984. ${ }^{[1]}$ Now, the effects of HR-HPV in cervical cancer are clearly recognized. ${ }^{[I]}$ More than $120 \mathrm{HPV}$ types have been identified. Among them, HPV types 16, I8, 31, 33, 35, 39, 45, 5I, 52, 56, 58, 59, 68, 73, and 82 are carcinogenic HR-HPV types demonstrating sexual transmission. ${ }^{[1]}$

HR-HPV, or oncogenic HPV types, are recognized causative agents of many cancers in women and men, including anogenital and oropharyngeal cancer. It has been estimated that HPV is responsible for nearly $5.2 \%$ of all cancers seen in the world. ${ }^{[9]}$ Among HPV-related cancers, cervical cancer has unique characteristics. Since HPV is observed in nearly all cases of cervical cancer in virological and epidemiological studies using the RT-PCR method, HPV is seen as the causative agent. ${ }^{[3]}$ In addition, HR-HPV was identified in all precursors of cervical cancer. Therefore, screening using the RT-PCR method has attracted growing attention. ${ }^{[10]}$

In studies on the prevalence of HPV-infection in women and the distribution of HPV types performed worldwide, differences in the rate of HPV infection have been reported to range between $6.1 \%$ and $45.6 \%$, depending on factors such as geographic region and age..$^{[5,6, \mathrm{II}]}$

In Turkey, the largest relevant multicenter series was performed by Dursun et al. ${ }^{[I]}$ In their study, the authors detected an HPV prevalence of $25 \%$. In other studies, HPV prevalence rates have ranged between $17.9 \%$ and $67.7 \% .^{[7,9,12,13]}$

In the present study, HPV prevalence was reported as $41.1 \%$. Our results are similar to those indicated by Kasap et al. ${ }^{[13]}$ from Turkey, and they are consistent with the 
Table 3. Most frequently seen types of human papilloma virus according to age group

\begin{tabular}{|c|c|c|c|c|c|c|c|c|c|c|}
\hline & & \multicolumn{2}{|c|}{$<30$ years } & \multicolumn{2}{|c|}{$30-39$ years } & \multicolumn{2}{|c|}{$40-49$ years } & \multicolumn{2}{|c|}{$\geq 50$ years } & \multirow[t]{2}{*}{$\mathbf{p}$} \\
\hline & & $\mathbf{n}$ & Column (\%) & $\mathbf{n}$ & $\%$ & $\mathbf{n}$ & $\%$ & $\mathbf{n}$ & Column (\%) & \\
\hline \multirow[t]{2}{*}{ HPV 16} & Negative & 97 & 83.6 & 245 & 86.6 & 224 & 88.5 & 169 & 91.4 & 0.203 \\
\hline & Positive & 19 & 16.4 & 38 & 13.4 & 29 & 11.5 & 16 & 8.6 & \\
\hline \multirow[t]{2}{*}{ HPV I8 } & Negative & 106 & 91.4 & 272 & 96.1 & 242 & 95.7 & 181 & 97.8 & 0.059 \\
\hline & Positive & 10 & 8.6 & II & 3.9 & 11 & 4.3 & 4 & 2.2 & \\
\hline \multirow[t]{2}{*}{ HPV 3I } & Negative & 105 & 90.5 & 266 & 94.0 & 240 & 94.9 & 174 & 94.1 & 0.445 \\
\hline & Positive & 11 & 9.5 & 17 & 6.0 & 13 & 5.1 & II & 5.9 & \\
\hline \multirow[t]{2}{*}{ HPV 5 I } & Negative & 107 & 92.2 & 274 & 96.8 & 239 & 94.5 & 173 & 93.5 & 0.212 \\
\hline & Positive & 9 & 7.8 & 9 & 3.2 & 14 & 5.5 & 12 & 6.5 & \\
\hline \multirow[t]{2}{*}{ HPV-positive } & Negative & 52 & 44.8 & 173 & 61.1 & 155 & 61.3 & 113 & 61.1 & 0.012 \\
\hline & Positive & 64 & 55.2 & 110 & 38.9 & 98 & 38.7 & 72 & 38.9 & \\
\hline \multirow[t]{4}{*}{ HPV-positive } & Negative & 52 & 44.8 & 173 & 61.1 & 155 & 61.3 & 113 & 61.1 & 0.040 \\
\hline & Single strain & 32 & 27.6 & 64 & 22.6 & 59 & 23.3 & 41 & 22.2 & \\
\hline & Multiple strain & 32 & 27.6 & 46 & 16.3 & 39 & 15.4 & 31 & 16.8 & \\
\hline & Total & 116 & 100.0 & 283 & 100.0 & 253 & 100.0 & 185 & 100.0 & \\
\hline
\end{tabular}

Chi-square test. HPV: Human papilloma virus.

Table 4. HPV positivity and its concordance with the cervical cytology

\begin{tabular}{|c|c|c|c|c|c|c|}
\hline & & \multicolumn{2}{|c|}{ HPV-negative } & \multicolumn{2}{|c|}{ HPV-positive } & \multirow[t]{2}{*}{$\mathbf{p}$} \\
\hline & & Count (n) & Row (\%) & Count (n) & Row (\%) & \\
\hline \multirow[t]{2}{*}{ Squamous cell atypia } & Yes & 417 & 66.3 & 212 & 33.7 & $<0.001^{*}$ \\
\hline & No & 76 & 36.5 & 132 & 63.5 & \\
\hline \multirow[t]{4}{*}{ Smear } & Negative & 417 & 66.3 & 212 & 33.7 & $<0.001^{* *}$ \\
\hline & ASCUS & 70 & 49.3 & 72 & 50.7 & \\
\hline & LSIL & 6 & 11.3 & 47 & 88.7 & \\
\hline & HSIL & 0 & 0.0 & 13 & 100.0 & \\
\hline
\end{tabular}

${ }^{*}$ Chi-square test; ${ }^{* *}$ Fisher's exact test. ASCUS: Atypical squamous cells of undetermined significance; HPV: Human papilloma virus; HSIL: High-grade squamous intraepithelial lesion; LSIL: Low-grade squamous intraepithelial lesion.

Table 5. Frequently seen human papilloma virus types in patients with squamous cell atypia

\begin{tabular}{|c|c|c|c|c|c|c|c|c|}
\hline & \multicolumn{8}{|c|}{ Smear } \\
\hline & \multicolumn{2}{|c|}{ Negative } & \multicolumn{2}{|c|}{ ASCUS } & \multicolumn{2}{|c|}{ LSIL } & \multicolumn{2}{|c|}{ HSIL } \\
\hline & Count (n) & Row (\%) & Count (n) & Row (\%) & Count (n) & Row (\%) & Count (n) & Row (\%) \\
\hline Human papilloma virus 16 & 57 & 55.9 & 26 & 25.5 & 13 & 12.7 & 6 & 5.9 \\
\hline Human papilloma virus 18 & 20 & 55.6 & 10 & 27.8 & 4 & II.I & 2 & 5.6 \\
\hline Human papilloma virus 3I & 26 & 50.0 & 15 & 28.8 & 7 & 13.5 & 4 & 7.7 \\
\hline Human papilloma virus $5 \mathrm{I}$ & 27 & 61.4 & 14 & 31.8 & 3 & 6.8 & 0 & 0.0 \\
\hline
\end{tabular}

ASCUS: Atypical squamous cells of undetermined significance; HSIL: High-grade squamous intraepithelial lesion; LSIL: Low-grade squamous intraepithelial lesion. 
world literature. ${ }^{[5]}$

While numerous studies performed have reported that globally, HPV 16 is the most prevalent type, HPV 18 and other oncogenic HPV types had similar incidence rates. The incidence rate of HPV types differs by geographic region. ${ }^{[5,6,14]}$

In our study, HPV 16 was the most frequently seen type of HPV, with a prevalence of $12.2 \%$, followed by HPV 3 I (6.2\%), HPV 5 I (5.3\%), and HPV I8 (4.3\%). Our results were similar to those of other studies performed in our country and in other areas of the world. ${ }^{[5,12,15,16]}$

In the literature, a bimodal distribution of HPV infection according to age has been reported. For example, in a study conducted by Senapati et al., HPV infection was most frequently seen in patients aged between 36 and 45 years, and those older than 55 years. ${ }^{[17]}$

In a study published by Bruni et al., the first peak was seen in patients younger than 25 , and second and third peaks were observed in cases older than 45 , and older than 65 years of age, respectively. ${ }^{[6,16,17]}$ Increased vulnerability of immature cervical epithelium at an early age, and exposure of cervical epithelium to HPV through sexual intercourse during the most active phase of squamous metaplasia have been reported as pathogenic factors underlying the first peak. ${ }^{[9]}$ Immunosenescence, changes in sexual behavior during middle age, or a cohort effect have been suggested as hypothetical risk factors for a peak incidence of HPV infection at a later age. It has been emphasized that rather than contracting a new infection at an advanced age, a depressed immune system may be responsible for reactivation of a persistent, latent, high-risk HPV infection. ${ }^{[6,7]}$

The second peak has been associated with factors that may be due to HPV types, host propensity, and previous screening programs. ${ }^{[6,8]}$ Alternatively, some literature studies have indicated that the prevalence of a second peak related to age is decreasing. ${ }^{[1,7,8,18]}$

In our study, HPV prevalence was higher in age the groups of those younger than 30 and older than 55 years of age. Our study was the first in this country to demonstrate a bimodal age distribution.

In the literature, infection with multiple HPV types has been reported in $20 \%$ to $50 \%$ of cases. ${ }^{[18,19]}$ In other studies examining the Turkish population, the prevalence rate of multiple-strain HPV infection has ranged between $18.3 \%$ and $38.7 \% .^{[9,12,15]}$ In this study, multiple HPV strains were detected in $17.7 \%$ of the cases, and were most frequently seen in the group of patients younger than 30 years of age, which is consistent with the literature data. ${ }^{[9,17,19]}$

The prevalence of HPV infection in women with SCA has reportedly ranged between $28.8 \%$ and $61.3 \%{ }^{[1,9,10]}$ However, in this study, HPV-positivity was detected in $63.5 \%$ of women demonstrating SCA. A significant correlation existed between SCA and HR-HPV positivity. The degree of atypia increased in parallel with HPV-positivity. The most frequently seen single strain in cytological samples demonstrating SCA was HPV $5 \mathrm{I}$ in the ASCUS group, and HPV 31 in the LSIL and HSIL groups.

HPV DNA positivity has been reported in $10.4 \%$ to $27 \%$ of cases without cytological atypia. ${ }^{[1, I I]}$ Although the role of HPV infection in the development of cervical cancer has been clearly recognized, it has been also reported that infection in women is eradicated by their immune system at a rate of $70 \%$ within the first year, and $90 \%$ within the second year, and that the type of HPV is important in the elimination of the virus. It has been also indicated that eradication of HR-HPV 16 and 18 in particular, which integrate their DNA with the DNA of the host, takes a long time. In a study performed among HPV DNA-positive students, the authors reported that within a period of 12 months, the HPV DNA levels decreased $70 \%$ within 12 months, and $80 \%$ after 18 months. In $10 \%$ of infected women, persistent infection and the development of cancer are seen within a period of 15 to 20 years. Therefore, the importance of cytological screening methods to detect lesions at an early phase of infection is clear. ${ }^{[3,7]}$

In our study, HPV DNA-positivity was detected in 33.7\% of the cases without cytological atypia. As a result, these patients were clinically monitored.

\section{Conclusion}

Patients who presented at a gynecology outpatient clinic of a tertiary health center were included in our study. Our results demonstrated a prevalence rate for HPV infection higher than previously reported for our country and demonstrated a bimodal distribution. A molecular test is of vital importance in the determination of HPV prevalence, the detection of frequently seen HPV types, and the development of protective measures for our country. However, it cannot adequately diagnose cervical dysplasia per se. Both our results and the literature findings indicate that molecular tests should be evaluated together with effective conventional screening tests and liquid-based cytological analysis.

Ethics Committee Approval

The protocol of this study was approved by the Dr. Lütfi Kırdar Training and Research Hospital Ethics Committee (2017/5 I4/III/4).

Informed Consent

Approval was not required.

Peer-review

Internally peer-reviewed.

Authorship Contributions

Concept: N.Ö.B.; Design: N.Ö.B., S.H.K.; Data collection 
\&/or processing: A.E.G., N.Ö.B., S.H.K.; Analysis and/or interpretation: H.G.Ö.; Literature search: N.Ö.B.; Writing: N.Ö.B., S.H.K., E.Ş.; Critical review: N.Ö.B., S.H.K., A.E.G.

\section{Conflict of Interest}

None declared.

\section{REFERENCES}

1. Dursun P, Ayhan A, Mutlu L, Çağlar M, Haberal A, Güngör T, et al. HPV Types in Turkey: Multicenter Hospital Based Evaluation of 6388 Patients in Turkish Gynecologic Oncology Group Centers. Turk Patoloji Derg 2013, 29:210-6. [CrossRef]

2. ICO Information Centre on HPV and Cancer. Available at: www. hpvcentre.net. Accessed Dec 15, 2016.

3. Akhan SE. Ülkemizde Servikal Kanser Epidemiyolojisi Ve HPV Serotipleri. ANKEM Derg 2007;21:96-8.

4. Bayram A, Derici YK, Yilmaz NO, Hanci SY, Agus N, Sirin CM, et al. Prevalence of high-risk human papillomavirus in women from Turkey. Clin Obstet Gynecol Reprod Med 2015;1:84-6. [CrossRef]

5. Akyar I, Aydın Ö, Yakıcıer MC, Kocagöz ZT, İnce Ü, Ünsal İ. Human papillomavirus prevalence and type in liquid-based cervical samples from Turkish women in a selected risk group. Turk J Med Sci 2013;43:963-70. [CrossRef]

6. Bruni L, Diaz M, Castellsagué X, Ferrer E, Bosch FX, de Sanjosé S. Cervical human papillomavirus prevalence in 5 continents: metaanalysis of 1 million women with normal cytological findings. J Infect Dis 2010;202:1789-99. [CrossRef]

7. Demir ET, Ceyhan M, Simsek M, Gunduz T, Arlier S, Aytac R, et al. The prevalence of different HPV types in Turkish women with a normal Pap smear. J Med Virol 2012;84:1242-7. [CrossRef]

8. Ersan G, Kose S, Senger SS, Gunes H, Sehirali S, Gurbuz I. The prevalence and risk factors of human papillomavirus in female sex workers. Eurasian J Med 2013;45:16-20. [CrossRef]

9. Yuce K, Pinar A, Salman MC, Alp A, Sayal B, Dogan S, et al. Detection and genotyping of cervical HPV with simultaneous cervical cytology in Turkish women: a hospital-based study. Arch Gynecol
Obstet 2012;286:203-8. [CrossRef]

10. Dursun P, Senger SS, Arslan H, Kuş̧̧u E, Ayhan A. Human papillomavirus (HPV) prevalence and types among Turkish women at a gynecology outpatient unit. BMC Infect Dis 2009;9:191. [CrossRef]

11. de Sanjosé S, Diaz M, Castellsagué X, Clifford G, Bruni L, Muñoz $\mathrm{N}$, et al. Worldwide prevalence and genotype distribution of cervical human papillomavirus DNA in women with normal cytology: a meta-analysis. Lancet Infect Dis 2007;7:453-9. [CrossRef]

12. Çolakoğlu Ş, Aka Bolat F, Çoban G. Human papilloma virus (HPV) prevalence and genotype distribution. J Clin Anal Med 2017;8:10913.

13. Kasap B, Yetimalar H, Keklik A, Yildiz A, Cukurova K, Soylu F. Prevalence and risk factors for human papillomavirus DNA in cervical cytology. Eur J Obstet Gynecol Reprod Biol 2011;159:168-71.

14. Damião PA, Oliveira-Silva M, Moreira MÂ, Poliakova N, de Lima ME, Chiovo J, et al. Human Papillomavirus types distribution among women with cervical preneoplastic, lesions and cancer in Luanda, Angola. Pan Afr Med J 2016;24:268.

15. Akcali S, Goker A, Ecemis T, Kandiloglu AR, Sanlidag T. Human papilloma virus frequency and genotype distribution in a Turkish population. Asian Pac J Cancer Prev 2013;14:503-6. [CrossRef]

16. Castle PE, Schiffman M, Herrero R, Hildesheim A, Rodriguez AC, Bratti MC, et al. A prospective study of age trends in cervical human papillomavirus acquisition and persistence in Guanacaste, Costa Rica. J Infect Dis 2005;191:1808-16. [CrossRef]

17. Senapati R, Nayak B, Kar SK, Dwibedi B. HPV Genotypes distribution in Indian women with and without cervical carcinoma: Implication for HPV vaccination program in Odisha, Eastern India. BMC Infect Dis 2017;17:30. [CrossRef]

18. Van SN, Khac MN, Dimberg J, Matussek A, Henningsson AJ. Prevalence of Cervical Infection and Genotype Distribution of Human Papilloma Virus Among Females in Da Nang, Vietnam. Anticancer Res 2017;37:1243-7. [CrossRef]

19. Pham TH, Nguyen TH, Herrero R, Vaccarella S, Smith JS, Nguyen Thuy TT, et al. Human papillomavirus infection among women in South and North Vietnam. Int J Cancer 2003;104:213-20. [CrossRef]

\section{Real-Time PCR Yöntemiyle HPV Çalışılan Hasta Grubunda Yüksek Risk HPV Prevalansı,} Tipleri ve Eş Zamanlı Yapılan Servikal Sıvı Bazlı Sitoloji ile HPV Uyumu

Amaç: Hastanemizdeki sıvı bazlı sitoloji yöntemiyle incelenen servikal sitoloji örnekleri ile eş zamanlı olarak real-time polimeraz zincir reaksiyonu (RT-PCR) yöntemiyle incelenen human papilloma virus (HPV) enfeksiyonunun prevalansını, en sık görülen tiplerini, normal ve anormal sitolojili kadınlardaki HPV tiplerini saptamak, HPV'nin sitoloji ile uyumunu incelemek ve ülkemiz istatistiklerine katkıda bulunmaktır.

Gereç ve Yöntem: Haziran 2016-Mart 2017 tarihleri arasındaki 837 hasta geriye dönük olarak çalışmaya alındı. HPV tiplerini saptamada RT-PCR yöntemi, eş zamanlı alınan servikal sitoloji örneklerinde ise Thin Prep yöntemi kullanılarak hastalara ait servikal sitoloji materyalleri değerlendirildi.

Bulgular: Sekiz yüz otuz yedi servikal sitolojinin 208'inde (\%24.9) skuamoz hücre atipisi (SHA) mevcut iken 629'unda (\%75.I) SHA görülmedi. SHA gösteren olguların I42'sinde (\%17.0) önemi belirsiz atipik skuamoz hücre (ASCUS], 53'ünde (\%6.3) düşük dereceli skuamoz intraepitelyal lezyon (LSIL), I3'ünde (\% I.6) yüksek dereceli skuamoz intraepitelyal lezyon (HSIL) mevcuttu. Sekiz yüz otuz yedi hastanın 344 'ünde HPV pozitifti (\%4I.I). En sık görülen HPV tipleri HPV tip I6, I8, 3I, 5I idi. HPV prevalansı 30 yaş altı ve 50 yaş üstü kadınlarda daha yüksekti. HPV 16'nın ve multipl suşlarının en sık görüldüğü yaş grubu 30 yaş altı gruptu. Tek suş olarak görülen en sık HPV tipi HPV 16 idi. HPV I6'yı HPV 5I, 3I ve 18 takip etmekteydi. Multipl en sık görülen HPV tipleri arasında HPV 16 ilk sırada iken bunu Tip 3I, Tip 5I ve Tip 18 izlemekteydi. SHA gösteren olguların 132'sinde (\%63.5) HPV pozitifliği mevcuttu. SHA içermeyen 4 I7 (\%66.3) hastada HPV negatif iken 2I2'sinde (\%33.7) HPV pozitifti.

Sonuç: Çalışmamızda en sık görülen HPV tipi HPV 16 idi. HPV prevalansında bimodal yaş dağıımı görülmekteydi. HPV prevalansı SHA derecesi ile korelasyon göstermekle birlikte SHA göstermeyen olgularda da RT-PCR ile yüksek oranda HPV pozitifliği saptandı. Bu durum HPV tipleri ve prevalansının belirlenmesinde, HPV pozitif hastaların gerektiği şekilde takip ve tedavi edilmesinde RT-PCR yöntemi ve sitolojik incelemenin birlikteliğinin önemini göstermektedir.

Anahtar Sözcükler: Human papilloma virus DNA; real-time polimeraz zincir reaksiyonu; servikal sitoloji. 